\title{
Application of Chemical Engineering Methodology in Process Development: A Case Study of MenD-catalyzed Synthesis of 6-Cyano-4-oxohexanoic Acid
}

\author{
M. Sudar, ${ }^{a}$ I. Dejanović, ${ }^{\text {, }, ~}$ M. Müller, ${ }^{b}$ \\ Đ. Vasić-Rački, ${ }^{a}$ and Z. Findrik Blaževića ${ }^{a, *}$ \\ anniversity of Zagreb, Faculty of Chemical Engineering and Technology, \\ Department of Reaction Engineering and Catalysis, \\ Savska cesta 16, 10000 Zagreb, Croatia \\ ${ }^{b}$ Institute of Pharmaceutical Sciences, Albert-Ludwigs-Universität \\ Freiburg, Albertstrasse 25, 79104 Freiburg, Germany
}

doi: 10.15255/CABEQ.2018.1393

Original scientific paper

Received: May 30, 2018

Accepted: December 21, 2018

To speed up evaluation, development and upscaling of new processes, the use of engineering methodology can have a great impact. Here we show the application of an engineering approach to find the reaction conditions allowing the best process metrics. An experimentally validated mathematical model for the MenD-catalyzed synthesis of a commercially unavailable product, 6-cyano-4-oxohexanoic acid, with a potential industrial use as a building block, was used for process optimization. Using the optimized conditions, $62.4 \mathrm{~g} \mathrm{dm}^{-3}$ of product, volume productivity of $87.1 \mathrm{~g} \mathrm{dm}^{-3} \mathrm{~d}^{-1}$, product yield of $96 \%$, and biocatalyst productivity of $25.8 \mathrm{~kg}_{\mathrm{P}} \mathrm{kg}^{-1} \mathrm{MenD}_{\mathrm{p}}$ can be achieved. Based on the optimized production procedure, economic analysis was performed to determine minimal product price required for project to be profitable in 8 years economic lifetime. In addition, Monte Carlo analysis (MCA) was used to assess the influence of uncertainties in estimation of input variables on overall economic performance.

Keywords:

mathematical modeling, process economics, Monte Carlo analysis, C-C coupling, enzyme catalysis, process engineering

\section{Introduction}

Biocatalysis holds great potential for the development of safe, green, and selective processes ${ }^{1,2}$. Thus, its industrial application for the production of pharma and fine chemicals has increased significantly over the years ${ }^{3}$ and there are several hundred biocatalytic industrial processes ${ }^{4,5}$. Easier access to enzymes and the ability to engineer the enzymes to meet the demands of industrial processes has certainly helped developments in that direction ${ }^{6}$. It is nowadays possible to carry out reactions catalyzed by enzymes with unnatural substrates, and by doing so, to gain access to new molecules that cannot be found in nature. One of such enzymes is $\mathrm{MenD}^{7}$ as it provides biocatalytic access to new types of products not related to the products currently accessible by thiamine diphosphate (ThDP) dependent enzyme catalysis $^{8,9}$. For further growth and development of biocatalysis, biochemical-engineering approaches can be very beneficial. They include the use of mo-

"Corresponding author: zfindrik@fkit.hr, ideja@fkit.hr, phone: +385 14597 157, fax: +3851 4597133 deling techniques ${ }^{10,11}$, process optimization tools ${ }^{12-14}$, as well as the use of early-stage economic assessment tool ${ }^{1,15}$. A model-based methodology can be used to define the process design search-space within which the optimal solution can be found; it can save development time and money as simulations increase the process understanding ${ }^{11}$, and it can have a favorable impact on product quality ${ }^{16}$. Pharmaceutical industry invests more money in product development and evaluation that fail than in successful products, which illustrates the importance of reducing cost and time for the development of industrial processes ${ }^{17}$. Consequently, any methodology or tool that can be used to evaluate process alternatives and speed up development can create a tremendous benefit. Whereas this approach is well established in the chemical and oil industry, its better exploitation is still expected in pharmaceutical industry ${ }^{2}$. Reaction engineering has long been used as an efficient and effective methodology to design and size the appropriate reactors for the synthesis of valuable industrial chemicals by chemical reactions ${ }^{2}$. The same can be done for biocatalytic reactions, but this approach is still underdeveloped in industrial settings. 


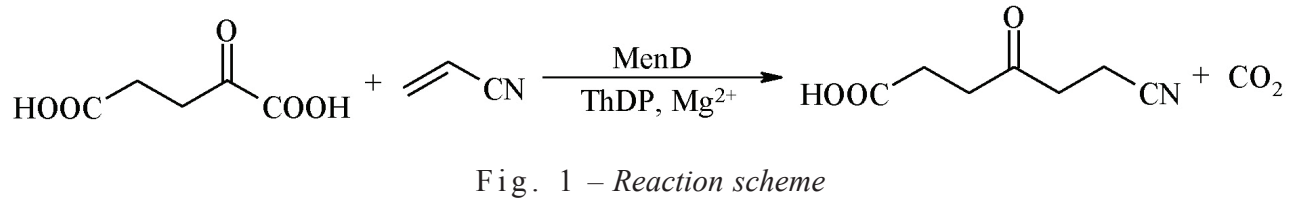

Even though comprehensive data are not always available, cost estimates should be made also at early stages of project development ${ }^{18}$. Simulation tools and a process model can help to analyze and assess suitable operating points in such complex process concepts at an early stage and reduce the experimental effort during the process ${ }^{19}$.

In this paper, a detailed analysis and optimization of the MenD-catalyzed reaction of acrylonitrile $(\mathrm{ACN})$ and $\alpha$-ketoglutaric acid (KGA) to synthesize 6-cyano-4-oxohexanoic acid (COHA) (Fig. 1) was conducted to achieve optimum process metrics, such as volume productivity, product concentration, and yield. The obtained data were used for the preliminary economic evaluation of the process. This MenD-catalyzed Stetter reaction with an unnatural acceptor substrate, i.e. ACN (Fig. 1), was first introduced in $2014^{8}$. The relevance of this reaction is in the potential application of COHA as a building block; the molecule contains a nitrile group, which can be used to synthesize other functional groups in a straightforward manner ${ }^{20}$. This paper is envisaged as a case study and demonstration of the application of an engineering approach in the early stage of process development.

\section{Methodology}

\section{Materials and apparatus}

Acrylonitrile $(\mathrm{ACN})$, disodium $\alpha$-ketoglutarate hydrate (KGA), p-methoxyphenol (PMP), and ThDP were purchased from Sigma Aldrich (Germany). Magnesium chloride was purchased from Acros Organics (Belgium). MenD was kindly provided by Prozomix Ltd. (United Kingdom) as a $2.274 \mathrm{mg} \mathrm{mL}^{-1}$ pure protein suspension in $3.2 \mathrm{M}\left(\mathrm{NH}_{4}\right)_{2} \mathrm{SO}_{4}$ solution. The reactor set-up and the main instrumentation used for the experimental studies was the same as in Ref. ${ }^{25}$

\section{Process description and the mathematical model}

Proposed reactor set-up is presented in Fig. 2. Based on the preliminary model simulations, the initial reaction mixture contains the reactants $\mathrm{ACN}$ $\left(120 \mathrm{mmol} \mathrm{dm}^{-3}\right)$ and KGA $\left(120 \mathrm{mmol} \mathrm{dm}^{-3}\right)$, as

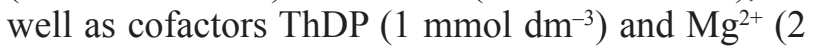
mmol dm${ }^{-3}$ ). Reactants should be present at equimolar concentrations. The reaction is started by adding the initial amount of MenD $\left(2.4 \mathrm{mg} \mathrm{cm}^{-3}\right)$ to the reactor. The feeding of all reaction components starts immediately after preparation of initial solution, and consists of two separate feeds. The addition of ACN (feed 1, $q_{1}$ ) was envisaged at the flowrate, which enables maintaining its concentration below $250 \mathrm{mmol} \mathrm{dm}^{-3}$ during the reaction. The addition of KGA, ThDP, $\mathrm{Mg}^{2+}$, and MenD is carried out through a separate feed (feed 2, $q_{2}$ ). Its purpose is, besides supplying the second substrate, to maintain the concentrations of ThDP and $\mathrm{Mg}^{2+}$ and the enzyme activity at appropriate levels, which decrease due to volume increase. Initial volume of 10 $\mathrm{m}^{3}$ is considered in simulations. As COHA is commercially unavailable, a moderate reaction mixture volume was chosen, since it is impossible to estimate its demand on the market.

The mathematical model ${ }^{25}$ of the process consists of the kinetic equations (Eqs. 1 and 3) and mass balances in the fed-batch reactor (Eqs. 4-11). According to experimental results, kinetic equation 1 is modified double substrate Michaelis-Menten kinetics with included noncompetitive inhibition by PMP, which is a stabilizing additive present in commercial ACN. This equation shows that the influence of ACN on the reaction rate can be described by linear dependency. Thus, it is a substrate which controls the reaction rate.

$$
\begin{gathered}
r=\frac{k \cdot f \cdot \gamma_{\mathrm{MenD}} \cdot c_{\mathrm{ACN}} \cdot c_{\mathrm{KGA}}}{K_{m}^{\mathrm{KGA}}+c_{\mathrm{KGA}}} \cdot \frac{1}{1+\frac{c_{\mathrm{PMP}}}{K_{i}^{\mathrm{PMP}}}} \\
f=\frac{c_{\mathrm{ThDP}} \cdot c_{\mathrm{Mg}^{2+}}}{\left(K_{m}^{\mathrm{ThDP}}+c_{\mathrm{ThDP}}\right) \cdot\left(K_{m}^{\mathrm{Mg}^{2+}}+c_{\mathrm{Mg}^{2+}}+\frac{c_{\mathrm{Mg}^{2+}}^{2}}{K_{i}^{\mathrm{Mg}^{2+}}}\right)}
\end{gathered}
$$

Eq. 2 depicts the influence of cofactors ThDP and $\mathrm{Mg}^{2+}$ on the reaction rate. These concentrations are usually maintained at constant level during the reaction, as they are a prerequisite for enzyme activity.

$$
r_{1}=k_{1} \cdot c_{\mathrm{ACN}}
$$

Eq. 3 presents the rate of $\mathrm{ACN}$ polymerization,

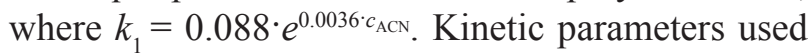
for all simulations are presented in Table 1.

Mass balances ${ }^{25}$ for KGA, ACN, COHA, PMP, MenD, ThDP, and $\mathrm{Mg}^{2+}$ in the fed batch reactor are presented by Eqs. 4-10. Eq. 11 presents the change 
Feed 1:

$\alpha$-ketoglutaric acid $\left(2.15 \mathrm{~mol} \mathrm{dm}^{-3}\right)$ $\operatorname{ThDP}\left(1.1 \mathrm{mmol} \mathrm{dm}^{-3}\right)$ $\mathrm{Mg}^{2+}\left(2.1 \mathrm{mmol} \mathrm{dm}^{-3}\right)$ $\operatorname{MenD}\left(3 \mathrm{mg} \mathrm{cm}^{-3}\right)$

Feed 2:

acrylonitrile

$\left(15.18 \mathrm{~mol} \mathrm{dm}^{-3}\right)$

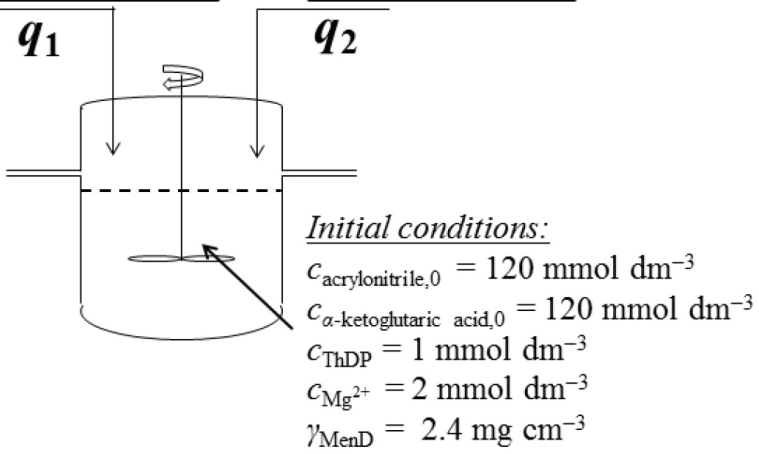

Fig. 2 -Fed-batch reactor set-up scheme

in reaction volume designated by the flow-rates of $\operatorname{ACN}\left(q_{1}\right)$ and $\operatorname{KGA}\left(q_{2}\right)$. As approximately constant concentrations of MenD, ThDP, and $\mathrm{Mg}^{2+}$ should ideally be maintained during the reaction, they are added together with KGA to the reactor.

$$
\begin{gathered}
\frac{\mathrm{d} c_{\mathrm{KGA}}}{\mathrm{d} t}=\frac{1}{V} \cdot\left(-c_{\mathrm{KGA}} \cdot \frac{\mathrm{d} V}{\mathrm{~d} t}+c_{\mathrm{KGA}, 0} \cdot q_{2}\right)-r \\
\frac{\mathrm{d} c_{\mathrm{ACN}}}{\mathrm{d} t}=\frac{1}{V} \cdot\left(-c_{\mathrm{ACN}} \cdot \frac{\mathrm{d} V}{\mathrm{~d} t}+c_{\mathrm{ACN}, 0} \cdot q_{1}\right)-r-r_{1} \\
\frac{\mathrm{d} c_{\mathrm{COHA}}}{\mathrm{d} t}=\frac{1}{V} \cdot\left(-c_{\mathrm{COHA}} \cdot \frac{\mathrm{d} V}{\mathrm{~d} t}\right)+r \\
\frac{\mathrm{d} c_{\mathrm{PMP}}}{\mathrm{d} t}=\frac{1}{V} \cdot\left(-c_{\mathrm{PMP}} \cdot \frac{\mathrm{d} V}{\mathrm{~d} t}+c_{\mathrm{PMP}, 0} \cdot q_{1}\right) \\
\frac{\mathrm{d} \gamma_{\mathrm{MenD}}}{\mathrm{d} t}=\frac{1}{V} \cdot\left(-\gamma_{\mathrm{MenD}} \cdot \frac{\mathrm{d} V}{\mathrm{~d} t}+\gamma_{\mathrm{MenD}, 0} \cdot q_{2}\right) \\
\frac{\mathrm{d} c_{\mathrm{ThDP}}}{\mathrm{d} t}=\frac{1}{V} \cdot\left(-c_{\mathrm{ThDP}} \cdot \frac{\mathrm{d} V}{\mathrm{~d} t}+c_{\mathrm{ThDP}, 0} \cdot q_{2}\right) \\
\frac{\mathrm{d} c_{\mathrm{Mg}}{ }^{2+}}{\mathrm{d} t}=\frac{1}{V} \cdot\left(-c_{\mathrm{Mg}^{2+}} \cdot \frac{\mathrm{d} V}{\mathrm{~d} t}+c_{\mathrm{Mg}^{2+}, 0} \cdot q_{2}\right) \\
\frac{\mathrm{d} V}{\mathrm{~d} t}=q_{1}+q_{2}
\end{gathered}
$$

Enzyme operational stability decay was described by the kinetics of the first order (Eq. 12), whereas the dependence of operational stability decay rate constant is directly proportional to the concentration of $\mathrm{ACN}$ (Eq. 13) ${ }^{25}$. This equation is valid up to $400 \mathrm{mmol} \mathrm{dm}^{-3}$ of $\mathrm{ACN}$, which is higher than $\mathrm{ACN}$ concentrations in the simulations to be shown in this work.

$$
\begin{gathered}
\frac{\mathrm{d} \gamma_{\mathrm{MenD}}}{\mathrm{d} t}=-k_{d} \cdot \gamma_{\mathrm{MenD}} \\
k_{d}=0.0045 \cdot c_{\mathrm{ACN}}
\end{gathered}
$$

The influence of feed flow-rates on the reaction outcome was evaluated. Feed $1\left(q_{1}\right)$ contained 15.15 mol dm${ }^{-3}$ solution of ACN, whereas feed $2\left(q_{2}\right)$ contained a mixture of KGA, ThDP, $\mathrm{Mg}^{2+}$, and $\mathrm{MenD}$ at concentrations of $2.5 \mathrm{~mol} \mathrm{dm}^{-3}, 1.1 \mathrm{mmol} \mathrm{dm}^{-3}$, $2.1 \mathrm{mmol} \mathrm{dm}^{-3}$, and $3 \mathrm{mg} \mathrm{cm}^{-3}$, respectively. The simulation time in the first set of simulations was fixed at 12 hours. Process metrics, i.e. volume productivity $\left(Q_{\mathrm{p}}\right)$, product concentration and yield $(Y)$, as well as biocatalyst productivity $(B P)$ were calculated in these simulations. In the second set of simulations, seven flow-rates $q_{1}$ and $q_{2}$ with the best process metrics outcome were selected, and simulations were done in more detail. Reactions were run as fed-batch for 12 hours, after which feeding was stopped and the reaction was simulated as batch until one of the substrates was completely consumed for easier purification. New process metrics were calculated for each simulation.

Table 1 -Estimated kinetic parameters in the MenD-catalyzed reaction of $K G A$ with $A C N^{25}$

\begin{tabular}{ccc}
\hline Parameter & Unit & Value \\
\hline$k$ & $\mathrm{~mL} \mathrm{mg}^{-1} \mathrm{~min}^{-1}$ & $0.0097 \pm 0.00009$ \\
$K_{m}^{\mathrm{KGA}}$ & $\mu \mathrm{mol} \mathrm{dm}{ }^{-3}$ & $46.09 \pm 4.32$ \\
$K_{m}^{\mathrm{ThDP}}$ & $\mu \mathrm{mol} \mathrm{dm}$ & $9.94 \pm 0.81$ \\
$K_{m}{ }^{\mathrm{Mg}^{2+}}$ & $\mu \mathrm{mol} \mathrm{dm}$ & $15.05 \pm 4.97$ \\
$K_{i}^{\mathrm{Mg}^{2+}}$ & $\mathrm{mmol} \mathrm{dm}{ }^{-3}$ & $6.44 \pm 2.59$ \\
$K_{i}^{\mathrm{PMP}}$ & $\mathrm{mol} \mathrm{dm}$ & $1.29 \pm 0.22$ \\
\hline
\end{tabular}


Volume productivity, $Q_{\mathrm{P}}$, was defined as the concentration of product divided by the reaction time. Product yield, $Y$, was defined as mols of product divided by the mols of ACN added to the reactor. Biocatalyst productivity, $B P$, was defined as $\mathrm{kg}$ of product divided by $\mathrm{kg}$ of enzyme added to the reactor.

Product isolation was carried out by lowering the $\mathrm{pH}$ of the reaction solution with $5 \mathrm{~mol} \mathrm{dm}^{-3} \mathrm{HCl}$ solution, and then the product was extracted by ethyl acetate. Organic phase was evaporated under reduced pressure to obtain COHA.

\section{Assumptions for the economic evaluation of the process}

The best result of the simulations was used as a starting point for early stage economic process analysis. Capital costs for the installation of the reactor were calculated based on the cost of $14 \mathrm{~m}^{3}$ glasslined carbon steel, agitated and jacketed reactor ${ }^{21}$, multiplied by Lang factor 5.7, typical for fluid processing units ${ }^{22}$. The reactor volume was chosen on the basis of the final volume of the reaction mixture, which was around $12 \mathrm{~m}^{3}$, taking into account that reactor can never be $100 \%$ full. Annualized equipment costs were determined by multiplying total capital investment with annuity factor $(k)$ calculated using Eq. 14.

$$
k=\frac{i}{1-(1+i)^{-t}}
$$

Operating costs were calculated based on raw material, waste management and utilities prices. Raw materials costs (RMC) were estimated based on market quotations of laboratory chemicals providers, divided by factor 10 . Ten batches per year were assumed. It was also assumed that the quantity of liquid waste requiring treatment is equal to added volumes of distilled water, ethyl acetate, and $\mathrm{HCl}$. The cost of waste treatment ${ }^{3}$ was estimated to be $2.00 € \mathrm{~m}^{-3}$. Energy cost of the process was assumed to be equal to cost of evaporation of ethyl acetate, based on $40 € \mathrm{t}^{-1}$ cost of medium pressure steam ${ }^{23}$, as reaction is conducted at $30^{\circ} \mathrm{C}$. Total operating expenses were estimated by adding $15 \%$ for fixed costs and $10 \%$ for maintenance to the annualized equipment costs. In this early stage of economic analysis, labor costs, cost of agitation and solvent regeneration were neglected, although these can have significant impact on economic feasibility.

To assess the influence of uncertainties in product cost estimation, Monte Carlo analysis (MCA) was performed to calculate break-even product price yielding zero net present value $(N P V)$ of the project after 8 years using discounted cash flow analysis. Economic lifetime of 8 years is typical for chemical processes ${ }^{3}$. NPV was calculated ${ }^{24}$ using Eq. 15, where $C_{T}$ represents total capital investment, $\Phi$ is the product price, $m$ is the production capacity per year, $t$ is the economic lifetime of the project, $T_{N}$ is tax percentage, $O_{N}$ is the yearly operating cost, and $r$ is the required internal rate of return.

$$
N P V=C_{T}+\sum_{n=1}^{t} \frac{\phi \cdot m \cdot\left(1-T_{N}\right)-O_{N}}{(1+r)^{n}}
$$

\section{Results and discussion}

\section{Kinetic modeling and its application to process optimization}

The previously developed and validated mathematical model (Eqs. 1-13) for the enzymatic synthesis of COHA (Fig. 1) was used for reaction optimization $^{25}$. During the kinetic investigation of MenD-catalyzed 1,4-addition of $\mathrm{KGA}$ to $\mathrm{ACN}^{25}$, it was found that $\mathrm{ACN}$ controls the reaction rate, i.e. specific activity (S.A.) of the enzyme (Fig. 3), as well as its operational stability, and the yield of the product. The latter is due to ACN spontaneous polymerization under the reaction conditions. With the aid of the kinetic model combined with mass balance equations in reactors, and substantiated by the experimental data ${ }^{25}$, it was found that the fed-batch reactor is the best choice for this reaction. By using this reactor, an inactivating effect of $\mathrm{ACN}$ on the enzyme can be minimized and polymerization rate can be kept at low level by simply controlling ACN concentration in the reactor. As its concentration also controls the reaction rate, the initial concentration was set to $120 \mathrm{mmol} \mathrm{dm}^{-3}$ in all simulations as a compromise between these factors. The ultimate optimization goals were the values of the process metrics presented in Table 2, which show the level required for the potential industrial exploitation. The focus was put on the evaluation of the effect of different process variables on volume productivity, yield of the product, and its final concentration. Biocatalyst productivity was also calculated for the optimal operational points. Thus, the objective of this optimization was to find the process conditions at which a compromise between the goal functions can be achieved.

Model simulations were done to evaluate the effect of feed flow-rates on volume productivity, product yield, and product concentration, the results of which are presented in Figs. 4a, b, and c, respectively. The results show which flow-rates of both feeds can be combined to achieve the best process metrics. This is very important since accumulation of ACN in the reactor is unwanted. Initially, a high range of flow-rates was evaluated for both feeds. It was found that flow-rates of $\mathrm{ACN}$ higher than 50 
$\mathrm{cm}^{3} \min ^{-1}$ cause significant accumulation of $\mathrm{ACN}$, thus, the upper limit of the investigated area was lowered to this value. In this area, the highest product yield limit that can be obtained is above $95 \%$ (Fig. 4a1), which is important for simplification of product isolation. Volume productivity and product concentration lower than maximum values, i.e. $Q_{\mathrm{p}}$ of $143 \mathrm{~g} \mathrm{dm}^{-3} \mathrm{~d}^{-1}$ and $c_{\mathrm{p}}$ of $442 \mathrm{mmol} \mathrm{dm}^{-3}$, will be achieved in this area. The maximum volume productivity and product concentration that can be achieved according to the simulations (Fig. 4b1 and $4 \mathrm{c} 1)$ are $Q_{\mathrm{p}}$ of $97.8 \mathrm{~g} \mathrm{dm}^{-3} \mathrm{~d}^{-1}$ and $c_{\mathrm{p}}$ of 299.4 mmol dm${ }^{-3}$, respectively. These simulations present results after a fed-batch process; however, it is envisaged that after feeding for 12 hours, the reactor is left in batch mode for the remaining substrates to react until one of them is spent.

Since process optimization with several goal functions, as in this case, cannot have a straight forward solution, it is clearly a compromise between them. Seven operating conditions, i.e. feed flowrates, were selected for further consideration (Table $3)$. Processes at these conditions were simulated in detail (batch mode following the 12 hours of feeding), and the results are presented in Fig. 5. Process metrics were recalculated, and are presented in

Table 2 -Typical process metrics goals for the potential industrial biocatalytic process carried out with free enzyme as catalyst (adapted from 1 and 15) to produce a pharma compound

\begin{tabular}{ll}
\hline Enzyme price & $1000-2500 € \mathrm{~kg}^{-1}$ \\
Volume productivity & $48 \mathrm{~g} \mathrm{dm}^{-3} \mathrm{~d}^{-1}$ \\
Product yield & $>80 \%$ \\
Product concentration & $50-100 \mathrm{~g} \mathrm{dm}^{-3}$ \\
Biocatalyst productivity & $10-100 \mathrm{~kg}_{\text {product }} \mathrm{kg}_{\text {enzyme }}^{-1}$ \\
Product price & $>100 € \mathrm{~kg}^{-1}$ \\
\hline
\end{tabular}

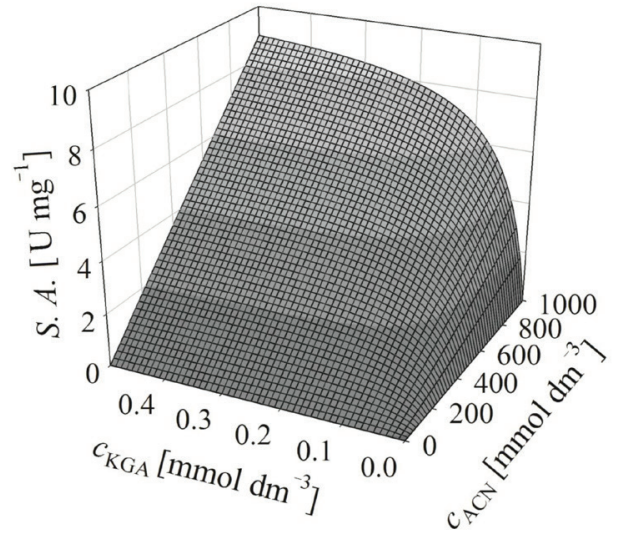

Fig. 3 - Influence of $A C N$ and KGA concentration on the specific enzyme activity (500 mmol dm $\mathrm{m}^{-3}$ phosphate buffer, $\mathrm{pH}$ 8.0, $\left.V_{r}=1 \mathrm{~cm}^{3}, 30^{\circ} \mathrm{C}, 1000 \mathrm{rpm}, \gamma_{\text {MenD }}=0.23 \mathrm{mg} \mathrm{cm}^{-3}\right)$. One unit of enzyme activity was defined as the amount of enzyme required to produce 1 mol of COHA per minute in $500 \mathrm{mmol} \mathrm{dm}^{-3}$ phosphate buffer $\mathrm{pH} 8.0$ and at $30^{\circ} \mathrm{C}$.

Table 3. For all seven selected operating conditions, significant values of process metrics were obtained. Nevertheless, experiments A, B, and C (Table 3, Fig. 5) were discarded from further consideration because product concentration $\left(\gamma_{\mathrm{p}}\right)$ was below $50 \mathrm{~g} \mathrm{dm}^{-3}$, whereas experiment $\mathrm{F}$ was discarded due to the obtained volume productivity $\left(Q_{\mathrm{p}}\right)$ below $48 \mathrm{~g} \mathrm{dm}^{-3} \mathrm{~d}^{-1}$. Experiment E, with the highest volume productivity $\left(Q_{\mathrm{p}}\right)$ of $87.1 \mathrm{~g} \mathrm{dm}^{-3} \mathrm{~d}^{-1}$, product concentration $\left(\gamma_{\mathrm{p}}\right)$ of $62.4 \mathrm{~g} \mathrm{dm}^{-3}$, and product yield $(Y)$ of $96 \%$ after 17 hours of reaction, was selected as the best for practical consideration and preliminary process economic evaluation. Nevertheless, experiments $\mathrm{D}$ and $\mathrm{G}$ also present viable options. Biocatalyst productivity $(B P)$ calculated from these data (Table 3) shows that in all cases industrial requirements were met. Additionally, it is important to emphasize that all simulations were done at $\mathrm{ACN}$ concentrations which ensure lower rates of enzyme operational stability decay $\left(<250 \mathrm{mmol} \mathrm{dm}^{-3}\right)$, and that, for example, in experiment $\mathrm{E}$, the process end-

Table 3 -Simulated process metrics for the seven selected reaction conditions (simulation conditions: $c_{A C N}=120 \mathrm{mmol} \mathrm{dm}^{-3}$,

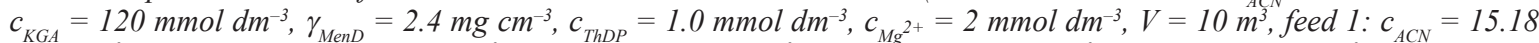
mol dm $m^{-3}$, feed 2: $c_{K G A}=2.15 \mathrm{~mol} \mathrm{dm}{ }^{-3}, c_{T h D P} \stackrel{\text { ThDP }}{=} 1.1 \mathrm{mmol} \mathrm{dm}^{-3}, c_{\mathrm{Mg}^{2+}} \stackrel{\mathrm{Mg}^{2}}{=} 2.1 \mathrm{mmol} \mathrm{dm}^{-3}, \gamma_{\text {MenD }}=3.0 \mathrm{mg} \mathrm{cm}^{-3}$ )

\begin{tabular}{c|cc|c|c|c|c|c}
\hline Exp & $\begin{array}{c}q_{1} \\
\left(\mathrm{dm}^{3} \mathrm{~min}^{-1}\right)\end{array}$ & $\begin{array}{c}q_{2} \\
\left(\mathrm{dm}^{3} \mathrm{~min}^{-1}\right)\end{array}$ & $\begin{array}{c}c_{\mathrm{P}} \\
\left(\mathrm{mmol} \mathrm{dm}^{-3}\right)\end{array}$ & $\begin{array}{c}\gamma_{\mathrm{P}} \\
\left(\mathrm{g} \mathrm{dm}^{-3}\right)\end{array}$ & $\begin{array}{c}Q_{p} \\
\left(\mathrm{~g} \mathrm{dm}^{-3} \mathrm{~d}^{-1}\right)\end{array}$ & $\begin{array}{c}Y \\
(\%)\end{array}$ & $\begin{array}{c}B P \\
\left(\mathrm{~kg}_{\mathrm{P}} \mathrm{kg}_{\text {MenD }}^{-1}\right)\end{array}$ \\
\hline A & 0.3 & 1.5 & 303.2 & 47.0 & 68.8 & 97 & 19.6 \\
B & 0.4 & 1.5 & 300.4 & 46.6 & 88.4 & 97 & 19.4 \\
C & 0.5 & 1.5 & 299.4 & 46.5 & 97.8 & 96 & 19.5 \\
D & 0.4 & 2.5 & 406.8 & 63.1 & 52.1 & 96 & 26.0 \\
E & $\mathbf{0 . 5}$ & $\mathbf{2 . 5}$ & $\mathbf{4 0 2 . 1}$ & $\mathbf{6 2 . 4}$ & $\mathbf{8 7 . 1}$ & $\mathbf{9 6}$ & $\mathbf{2 5 . 8}$ \\
F & 0.4 & 3.0 & 416.5 & 64.6 & 28.5 & 96 & 26.4 \\
G & 0.5 & 3.0 & 452.7 & 70.2 & 58.0 & 96 & 28.9 \\
\hline
\end{tabular}


(a)

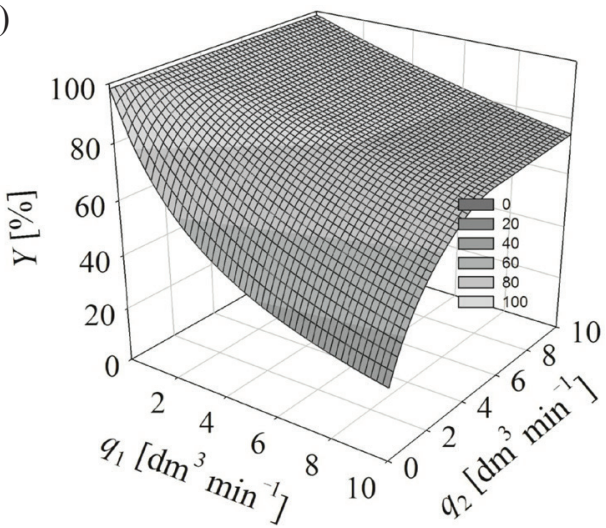

(b)

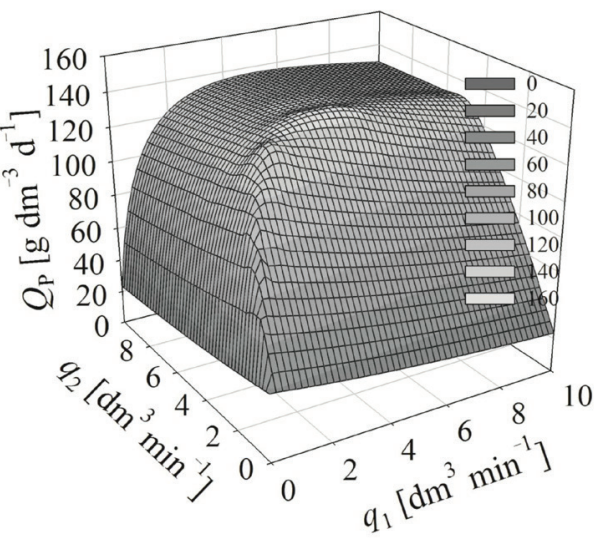

(c)

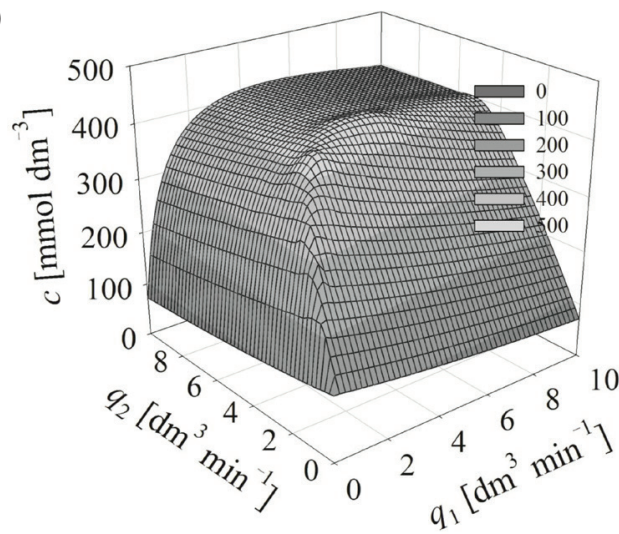

(a1)

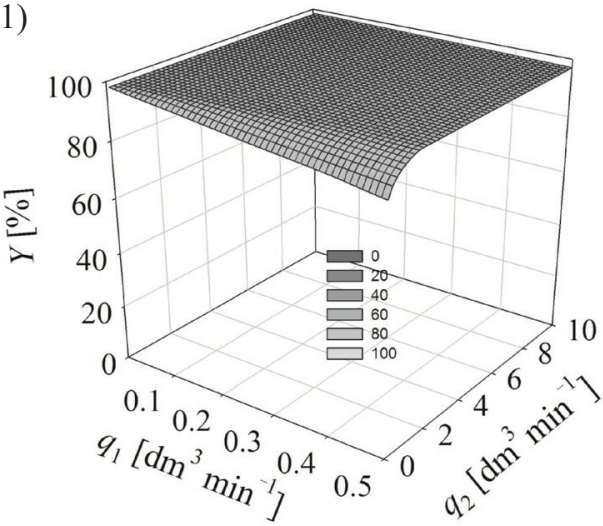

(b1)

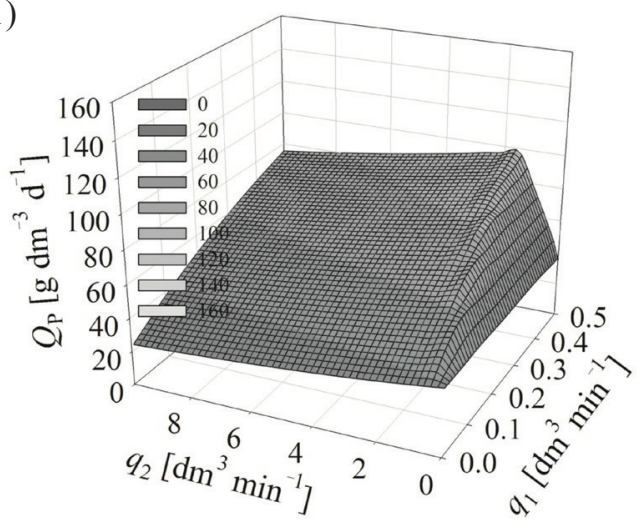

(c1)

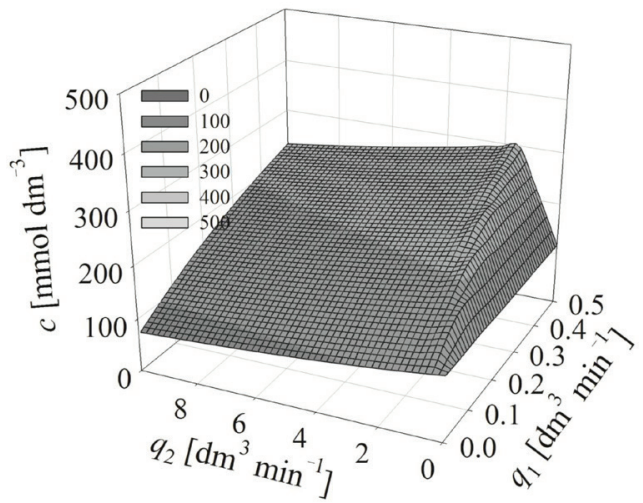

Fig. 4 - Simulations of the COHA synthesis in the fed-batch reactor $\left(500 \mathrm{mmol} \mathrm{dm}{ }^{-3}\right.$ phosphate buffer $\mathrm{pH} 8.0,30{ }^{\circ} \mathrm{C}, 1000 \mathrm{rpm}$, $V_{\text {reactor } 0}=10 \mathrm{~m}^{3}, c_{A C N}=120 \mathrm{mmol} \mathrm{dm}{ }^{-3}, c_{K G A}=120 \mathrm{mmol} \mathrm{dm}{ }^{-3}, \gamma_{M e n D}=2.4 \mathrm{mg} \mathrm{cm}^{-3}, c_{T h D P}=1.0 \mathrm{mmol} \mathrm{dm}^{-3}, c_{\mathrm{Mg}^{2+}}=2 \mathrm{mmol} \mathrm{dm} \mathrm{mm}^{-3}$, feed

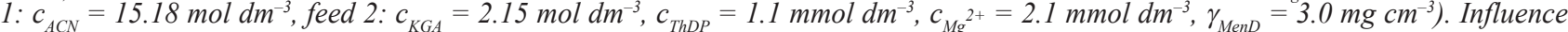
of feed flow rates on: a) product yield; b) volume productivity; c) product concentration. a1., b1., and cl. represent the more focused area where optimal conditions are searched.

ed with enzyme activity at $89 \%$ of initial activity. This means that enzyme can be reused and even higher values of $B P$ can be reached. For the purpose of simplification, it was assumed that enzyme would be used only once. The final reaction mixture volume is $12 \mathrm{~m}^{3}$ and $62.4 \mathrm{~g} \mathrm{dm}^{-3}$ of product is obtained (Table 3, Exp. E).

\section{Evaluation of preliminary process economics}

With assumed 10 batches per year, total yearly capacity of the plant is estimated to be approxi- mately $7,520.00 \mathrm{~kg}$. Total capital investment of the plant was estimated to be $399,761.13 €$. Annualized equipment cost was estimated to be $81,296.47 €$, based on $6 \%$ interest rate $(i)$ and economic lifetime of 8 years $(t)$, typical for chemical processes ${ }^{3}$. Quantities of raw materials used for synthesis in a $12 \mathrm{~m}^{3}$ batch are presented in Table 4. Enzyme price ${ }^{1}$ was assumed to be $2500 € \mathrm{~kg}^{-1}$. Total annual operating expenses based on 10 batches per year are presented in Table 5 . The estimated yearly amount of $260.4 \mathrm{~m}^{3}$ of waste leads to the waste treatment cost of $528 €$ per year. 
(a)

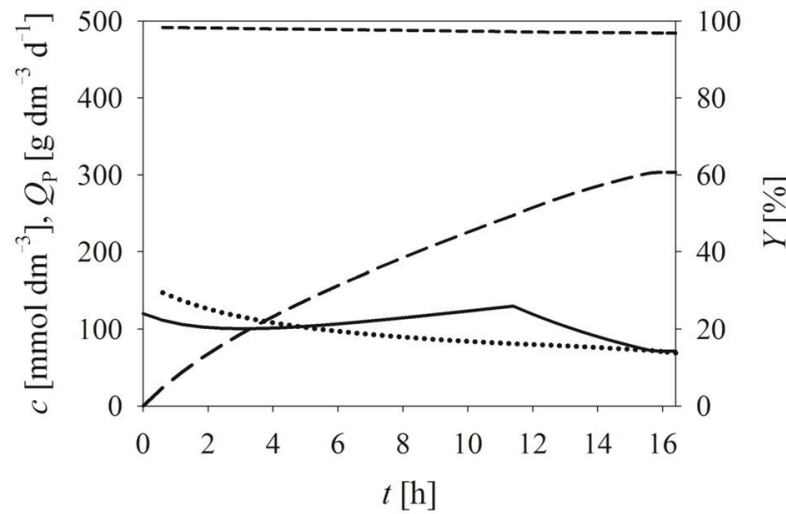

(c)

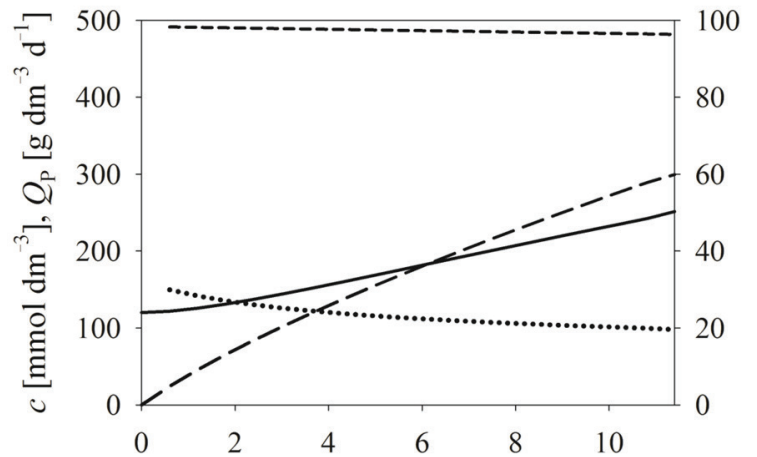

$t[\mathrm{~h}]$

(e)

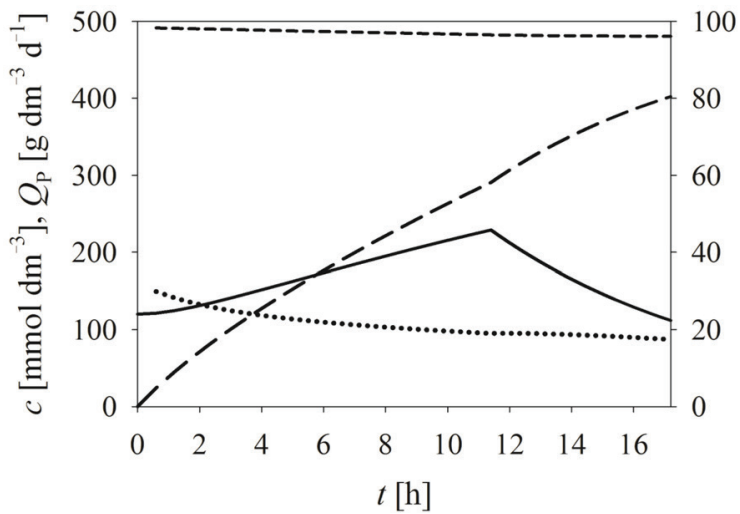

(b)

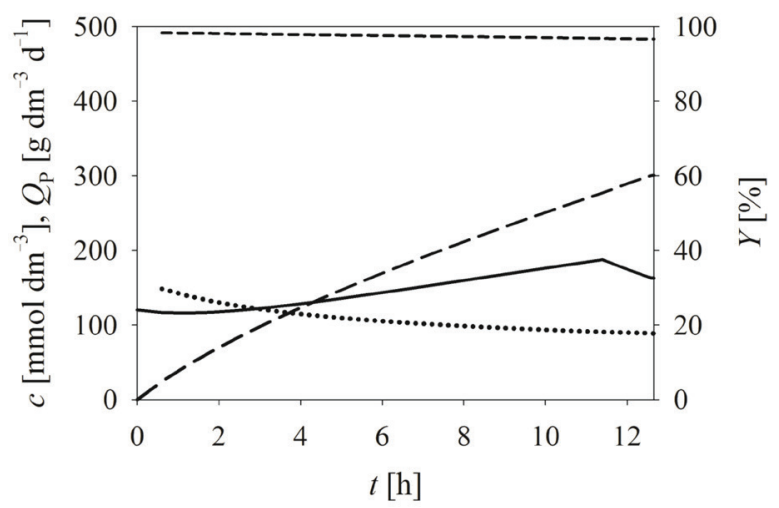

(d)

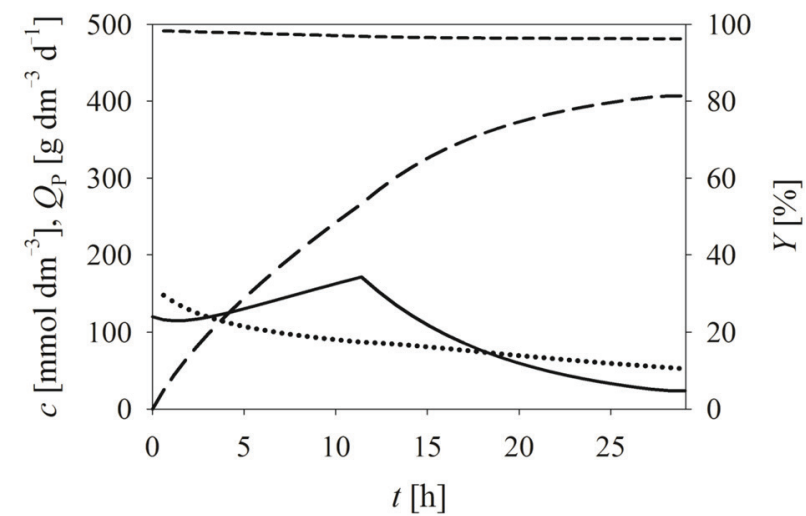

(f)

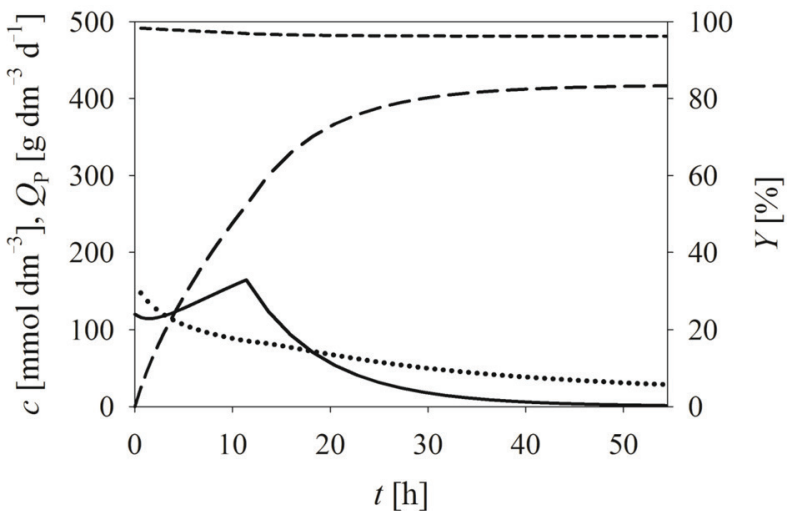

(g)

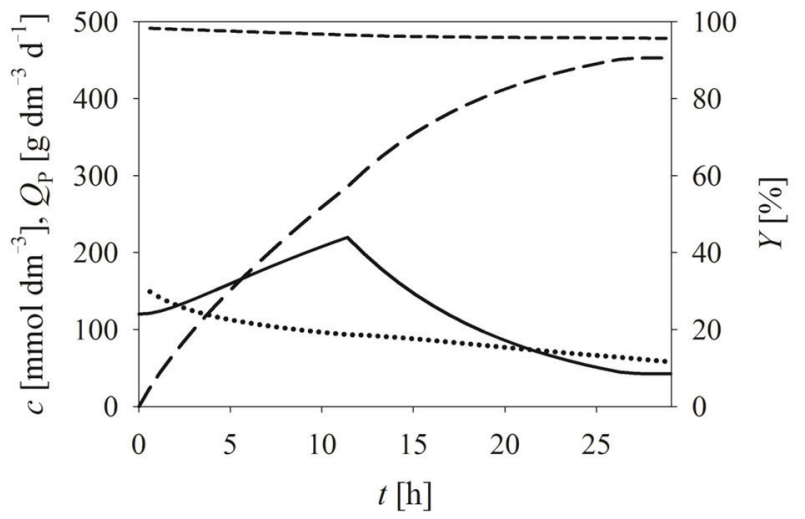

Fig. 5 - Simulations of the fed-batch/batch processes for the selected optimal conditions presented in Table 3.

Legend: line - acrylonitrile, long dash line - COHA, dotted line - volume productivity, short dash line - product yield. 
Table 4 -Estimated raw material costs per one cycle/batch

\begin{tabular}{l|r|r|r}
\hline \multicolumn{1}{c}{ Chemical } & \multicolumn{1}{c}{ Quantity } & Unit price & \multicolumn{1}{c}{ Cost } \\
\hline ACN & \multicolumn{4}{c}{ Synthesis step } \\
KGA & $421.07 \mathrm{dm}^{3}$ & $3.85 € \mathrm{dm}^{-3}$ & $1,621.12 €$ \\
$\mathrm{MenD}$ & $975.5 \mathrm{~kg}$ & $134.00 € \mathrm{~kg}^{-1}$ & $130,717.00 €$ \\
$\mathrm{ThDP}$ & $29.13 \mathrm{~kg}$ & $2,500.00 € \mathrm{~kg}^{-1}$ & $72,825.00 €$ \\
$\mathrm{MgCl}_{2}$ & $5.47 \mathrm{~kg}$ & $4,925.00 € \mathrm{~kg}^{-1}$ & $26,939.75 €$ \\
Distilled water & $12,000.00 \mathrm{dm}^{3}$ & $0,0005 € \mathrm{dm}^{-3}$ & $6.00 €$ \\
$\mathrm{KH}_{2} \mathrm{PO}_{4}$ & $40.80 \mathrm{~kg}$ & $9.10 € \mathrm{~kg}^{-1}$ & $371.28 €$ \\
$\mathrm{~K}_{2} \mathrm{HPO}_{4}$ & $818.70 \mathrm{~kg}$ & $19.80 € \mathrm{~kg}^{-1}$ & $16,210.26 €$ \\
\hline & \multicolumn{4}{c}{ Product isolation step } \\
\hline Ethyl acetate & $12,000.00 \mathrm{dm}^{3}$ & $4.52 € \mathrm{dm}^{-3}$ & $54,240.00 €$ \\
HCl & $2,400.00 \mathrm{dm}^{3}$ & $3.44 € \mathrm{dm}^{-3}$ & $8,256.00 €$ \\
\hline Total RMC & $46.50 € \mathrm{~kg}^{-1}$ & $106.49 €$ \\
\hline
\end{tabular}

Table 5 - Annual operating costs (10 cycles)

\begin{tabular}{lr|r}
\hline & \multicolumn{1}{|c|}{ Total } & Per kg product \\
\hline RMC & $3,112,929.0 €$ \\
Operating costs & $183.2 €$ \\
Waste treatment & $528 €$ \\
Fixed expenses & $12,194.0 €$ \\
Maintenance & $8,129.6 €$ & \\
\hline Total & $3,133,963.80 €$ & $416.8 € \mathrm{~kg}^{-1}$ \\
\hline
\end{tabular}

Table 6 - Mode, minimum, and maximum values of independent variables used in $M C A$

\begin{tabular}{ccccc}
\hline Variable & Minimum & Mode & Maximum \\
\hline$C_{T}$ & $-20 \%$ & $399,761.1 €$ & $+50 \%$ \\
$T_{N}$ & $-30 \%$ & $42 \%$ & $+30 \%$ \\
$O_{N}$ & $-10 \%$ & $3,112,929.0 €$ & $+30 \%$ \\
$r$ & $-30 \%$ & $10 \%$ & $+30 \%$ \\
\hline
\end{tabular}

For the MCA 5000, independent variables' datasets were generated using triangular distribution according to mode, and maximum and minimum values in percentages, given in Table 6 .

For each point, product price value yielding $N P V=0$ was calculated to assess minimal product price required. Results are presented in Fig. 6. It can be seen that the minimum product cost (MPC) yielding $N P V=0$ in 8 years with highest probability is $790 € \mathrm{~kg}^{-1}$, and in $95 \%$ of analysed scenarios, MPC is lower than $940 € \mathrm{~kg}^{-1}$. Ten percent values of market quotations for similar products show much higher prices: 4-oxohexanoic acid ${ }^{26}$ is $288 € \mathrm{~g}^{-1}$ and 6-nitro-4-oxohexanoic acid ${ }^{27}$ is $12.8 € \mathrm{~g}^{-1}$.

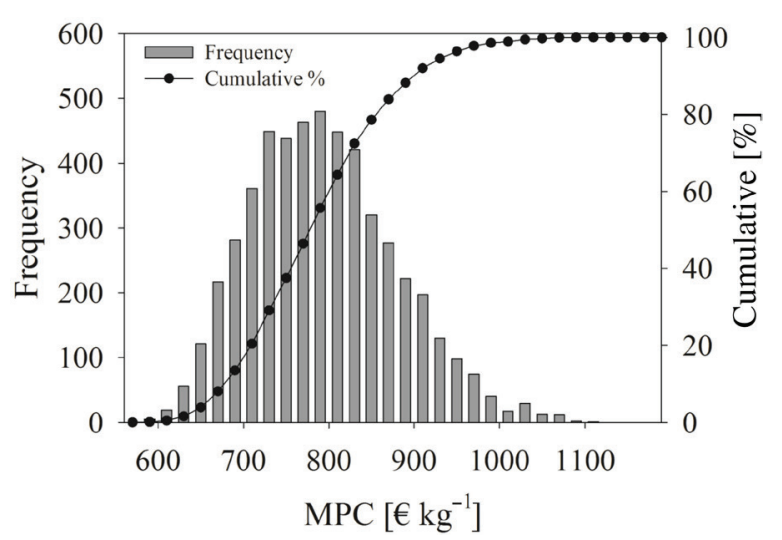

Fig. 6 - Histogram and cumulative probability diagram of minimum product costs (MPC)

\section{Conclusions}

It was shown how process model based on reliable kinetic data could be used for process optimization as well as a sound basis for preliminary calculation of process costs. An optimal operating point that was selected based on the compromise of different process metrics enabled obtaining $62.4 \mathrm{~g} \mathrm{dm}^{-3}$ of product, volume productivity of $87.1 \mathrm{~g} \mathrm{dm}^{-3} \mathrm{~d}^{-1}$, product yield of $96 \%$, and biocatalyst productivity of $25.8 \mathrm{~kg}_{\mathrm{p}} \mathrm{kg}^{-1} \mathrm{MenD}$. These numbers were a prerequisite for further process consideration, and based on the selected solution, an early-stage economic analysis was conducted. The most probable product price which could guarantee the return of the investment after 8 years was estimated at $790 € \mathrm{~kg}^{-1}$, which is significantly lower than a similar product on the market. Even with additional costs for labour and agitation taken into consideration, preliminary cost analysis confirms the potential viability of the process at this early stage of process development.

\section{ACKNOWLEDGMENTS}

This project has received funding from the European Union's Horizon 2020 Research and Innovation Program under Grant Agreement No. 635595 (CarbaZymes). This communication reflects only the beneficiary's view, and the European Commission is not responsible for any use that may be made of the information it contains. Authors would like to thank Prozomix Ltd., United Kingdom for providing the enzyme for experimental studies.
List of symbols
$B P \quad$ - biocatalyst productivity, $\mathrm{kg}_{\text {product }} \mathrm{kg}^{-1}$ enzyme
c $\quad$ - molar concentration, $\mathrm{mmol} \mathrm{\textrm {dm } ^ { - 3 }}$
$C_{T} \quad-$ total capital investment, $€$ 
$f-$ - coefficient that quantifies the effect of ThDP and $\mathrm{Mg}^{2+}$ concentration (Eq. 3)

$k \quad-$ annuity factor (Eq. 14)

$k \quad-$ kinetic constant of the first order, $\min ^{-1}$

$k_{d} \quad-$ operational stability decay rate constant, $\mathrm{h}^{-1}$

$K_{i} \quad$ - inhibition constant, $\mathrm{mmol} \mathrm{dm}^{-3}$

$K_{m} \quad-$ Michaelis constant, $\mathrm{mmol} \mathrm{dm}^{-3}$

$m \quad-$ production capacity per year, $\mathrm{kg}$

$N P V \quad-$ net present value, $€$

$O_{N} \quad$ - yearly operating cost, $€$

$q \quad-$ volume flow rate, $\mathrm{cm}^{3} \mathrm{~min}^{-1}$

$q_{1} \quad-$ volume flow rate of acrylonitrile in the fed-batch experiment, $\mathrm{cm}^{3} \mathrm{~min}^{-1}$

$q_{2} \quad-$ volume flow rate of the second feed in the fed-batch experiment containing ThDP, $\alpha$-ketoglutaric acid and $\mathrm{Mg}^{2+}$ salt, $\mathrm{cm}^{3} \mathrm{~min}^{-1}$

$Q_{P} \quad-$ volume productivity, $\mathrm{g} \mathrm{dm}^{-3} \mathrm{~d}^{-1}$

$r \quad-$ required internal rate of return, years

$r \quad-$ reaction rate of enzymatic reaction, $\mathrm{mmol} \mathrm{dm}{ }^{-3} \min ^{-1}$

$r_{1} \quad-$ reaction rate of acrylonitrile polymerization, $\mathrm{mmol} \mathrm{dm}{ }^{-3} \mathrm{~min}^{-1}$

S.A. $\quad-$ specific enzyme activity, $\mathrm{U} \mathrm{mg}^{-1}$

$t \quad-$ reaction time, $\min$

$t \quad-$ economic lifetime of the project, year

$T_{N} \quad-\operatorname{tax}, \%$

$V_{m} \quad-$ maximum reaction rate, $\mathrm{U} \mathrm{mg}^{-1}$

$V \quad$ - reactor volume, $\mathrm{m}^{3}$

$Y \quad$ - product yield, \%

$\gamma \quad-$ mass concentration, $\mathrm{mg} \mathrm{cm}^{-3}$

$\Phi \quad$ - product price, $€$

\section{Abbreviations}

ACN - acrylonitrile

COHA - 6-cyano-4-oxohexanoic acid

KGA $-\alpha$-ketoglutaric acid

MCA - Monte Carlo analysis

MenD - 2-succinyl-5-enolpyruvyl-6-hydroxy-3-cyclohexene-1-carboxylate synthase

MPC - minimum product cost

PMP $-p$-methoxyphenol

RCA - raw materials cost

ThDP - thiamine diphosphate

\section{References}

1. Tufvesson, P., Lima-Ramos, J., Nordblad, M., Woodley, J. M., Guidelines for cost analysis for catalyst production in biocatalytic processes, Org. Proc. Res. Dev. 15 (2011) 266. doi: https://doi.org/10.1021/op1002165

2. Ringborg, R. H., Woodley, J. M., The application of reaction engineering to biocatalysis, React. Chem. Eng. 1 (2016) 10. doi: https://doi.org/10.1039/c5re00045a
3. Tufvesson, P., Nordblad, M., Krühne, U., Schürmann, M., Vogel, A., Wohlgemuth, R., Woodley, J. M., Economic considerations for selecting an amine donor in biocatalytic transamination, Org. Process Res. Dev. 19 (2015) 652. doi: https://doi.org/10.1021/acs.oprd.5b00100

4. Pollard, D. J., Woodley, J. M., Biocatalysis for pharmaceutical intermediates: The future is now, Trends Biotechnol. 25 (2007) 66. doi: https://doi.org/10.1016/j.tibtech.2006.12.005

5. Schmid, A., Dordick, J. S., Hauer, B., Kiener, A., Wubbolts, M., Witholt, B., Industrial biocatalysis today and tomorrow, Nature 409 (2001) 258 doi: https://doi.org/10.1038/35051736

6. Truppo, M. D., Biocatalysis in the pharmaceutical industry - the need for speed, ACS Med. Chem. Lett. 8 (2017) 476. doi: https://doi.org/10.1021/acsmedchemlett.7b00114

7. Fang, M., Macova, A., Hanson, K. L., Kos, J., Palmer, D. $R$. J., Using substrate analogues to probe the kinetic mechanism and active site of Escherichia coli MenD, Biochemistry $\mathbf{5 0}$ (2011) 8712. doi: https://doi.org/10.1021/bi201202n

8. Beigi, M., Waltzer, S., Zarei, M., Müller, M., New Stetter reactions catalyzed by thiamine diphosphate dependent MenD from E. coli, J. Biotechnol. 191 (2014) 64. doi: https://doi.org/10.1016/j.jbiotec.2014.07.451

9. Beigi, M., Gauchenova, E., Walter, L., Waltzer, S., Bonina, F., Stillger, T., Rother, D., Pohl, M., Müller, M., Regio- and stereoselective aliphatic-aromatic cross-benzoin reaction: Enzymatic divergent catalysis, Chem. Eur. J. 22 (2016) 13999. doi: https://doi.org/10.1002/chem.201602084

10. Al-Haque, N., Santacoloma, P., Lima, W., Tufvesson, P., Rafigul, G., Woodley, J., A robust methodology for kinetic model parameter estimation for biocatalytic reactions, Biotechnol. Prog. 28 (2012) 1186. doi: https://doi.org/10.1002/btpr.1588

11. Vasić-Rački, Đ., Findrik, Z., Vrsalović Presečki, A., Modelling as a tool of enzyme reaction engineering for enzyme reactor development, Appl. Microbiol. Biotechnol. 91 (2011) 845 . doi: https://doi.org/10.1007/s00253-011-3414-0.

12. Braun, M., Link, H., Liu, L., Schmid, R. D., Weuster-Botz, $D$., Biocatalytic process optimization based on mechanistic modeling of cholic acid oxidation with cofactor regeneration, Biotechnol. Bioeng. 108 (2011) 1037. doi: https://doi.org/10.1002/bit.23047

13. Findrik, Z., Németh, G., Gubicza, L., Bélafi-Bakó, K., Vasić-Rački, Đ., Evaluation of factors influencing the enantioselective enzymatic esterification of lactic acid in ionic liquid, Bioproc. Biosyst. Eng. 35 (2012) 625. doi: https://doi.org/10.1007/s00449-011-0645-5

14. Findrik, Z., Poljanac, M., Vasić-Rački, Đ., Modelling and optimization of the $(R)-(+)-3,4$-dihydroxyphenyllactic acid production catalyzed with D-lactate dehydrogenase from Lactobacillus leishmannii using genetic algorithm, Chem. Biochem. Eng. Q. 19 (2005) 351.

15. Tufvesson, P., Lima-Ramos, J., Al Haque, N., Gernaey, K. V., Woodley, J. M., Advances in the process development of biocatalytic processes, Org. Proc. Res. Dev. 17 (2013) 1233. doi: https://doi.org/10.1021/op4001675

16. Román-Martínez, A., Woodley, J. M., Gani, R., Design of novel integrated pharmaceutical processes: A model-based approach, In book: Comprehensive quality by design for pharmaceutical product development and manufacture, Reklaitis G. V., Seymour C. and Garcia-Munoz, S. Eds., Wiley, 2017, pp.71-93. doi: https://doi.org/10.1002/9781119356189.ch5 
17. Petrides, D. P., Koulouris, A., Lagonikos, P. T., The role of process simulation in pharmaceutical process development and product commercialization, Pharm. Eng. 22 (1) (2002) 1.

18. Kirk-Othmer, Encyclopedia of Chemical Technology, $5^{\text {th }}$ Ed.,Hoboken, N. J.: Wiley-Interscience, 2004.

19. Wagner, N., Bosshart, A., Wahler, S., Failmezger, J., Panke, S., Bechtold, M., Model-based cost optimization of a reaction-separation integrated process for the enzymatic production of the rare sugar D-psicose at elevated temperatures, Chem. Eng. Sci. 137 (2015) 423.

doi: https://doi.org/10.1016/j.ces.2015.05.058

20. Zou, T., Yu, X., Feng, X., Bao, M., An efficient transformation of primary halides into nitriles through palladium-catalyzed hydrogen transfer reaction, Chem. Comm. 51 (2015) 10714. doi: https://doi.org/10.1039/C5CC03429A.

21. http://www.matche.com/equipcost/Reactor.html (accessed 19. 09. 2018.)
22. Peters, M. S., Timmerhaus, K. D., Plant design and economics for chemical engineers, McGraw-Hill International Editions, 1991, p. 184.

23. https://www.intratec.us/chemical-markets/steam-prices (accessed 14. 05. 2018.)

24. Shemfe, M., Gu, S., Fidalgo, B., Techno-economic analysis of biofuel production via bio-oil zeolite upgrading: An evaluation of two catalyst regeneration system, Biomass Bioenergy 98 (2017) 182.

doi: https://doi.org/10.1016/j.biombioe.2017.01.020

25. Sudar, M., Vasić-Rački, Đ., Müller, M., Walter, A., Findrik Blažević, Z., Mathematical model of the MenD-catalyzed 1,4-addition (Stetter reaction) of $\alpha$-ketoglutaric acid to acrylonitrile, J. Biotechnol. 268 (2018) 71. doi: https://doi.org/10.1016/j.jbiotec.2018.01.013

26. https:/www.sigmaaldrich.com/catalog/product/aldrich/ s574090? lang=en\&region $=\mathrm{HR}$ (accessed 25. 05. 2018.)

27. http://alinda.ru/finechem_en_html?i=ALBB-027728 (accessed 25. 05. 2018.) 